\title{
Managing Entrepreneurship Education for Economic Security at University Level in Cross River State
}

\author{
Uchendu, C. C. \\ Osim, R. 0. \\ Odigwe, F. N \\ Department of Educational Administration and Planning, Faculty of Education University of Calabar, Calabar \\ chikauchendu@yahoo.com
}

\section{Doi:10.5901/jesr.2015.v5n2p261}

\begin{abstract}
The increasing rate of unemployment, poverty and dependence among Nigerian university products had necessitated the introduction of entrepreneurship education for economic security. This study investigated Management of Entrepreneurship Education for Economic Security in Universities in Cross River State. Two hypotheses were formulated to guide the study. Ex post facto design was adopted for the study. Forty (40) core and general managers from the two universities made up the population. Since the population was small, the entire 40 core and general managers were used and they responded to the questionnaire. The researchers developed an instrument called "Management of Entrepreneurship Education for Economic Security Questionnaire" (MEEESQ) for data collection. Data collected were analyzed with Pearson Product Moment Correlation Analysis and Independent t-test statistical techniques. Results revealed that there is a significant relationship between management of entrepreneurship education and economic security. Conventional and specialized universities do not differ in their management of entrepreneurship education for economic security. It was recommended that priority should be accorded to the management of entrepreneurship education in universities for economic security. This will equip students with skills for business and economic stability.
\end{abstract}

Keywords: Entrepreneurship Education, Management, Universities, Economic Security.

\section{Introduction}

Education is a powerful and potent instrument for development and economic growth in every nation. Education at university level is the engine hub for total development of man where students are given opportunity to develop in the three educational domains- cognitive, affective and psychomotor domain. This training equips the learners with right knowledge and skills that will make them functional and useful members of the society, hence contribute to national development and building a strong economy. With the above educational goal, it is expected that job opportunities should follow closely to graduation to promote the realization of this goal in Nigeria. On the contrary, condition of graduates in Nigeria appears different as unemployment, poverty etc have been on increase irrespective of government programmes such as National Directorate of Employment (NDE) and others (Igbatigbi, 2007). Today many products of university education do not have what it takes to rely on themselves or building economic security over a life time. Economic security or financial security is the condition of having stable income and other resources to support a standard of living now and in the foreseeable future (Childstats, 2007). Rupert (2007) opines that economic security is a situation of having a stable source of financial income that allows for the on-going maintenance of one's standard of living.

The population of university graduates is increasing on yearly basis and attention is focused on the white collar jobs in government establishment and blue-chip companies. Unfortunately, succor is really found in any of these establishments rather high level of unemployment is observed. This is causing some level of threats in the society in form of violence, poverty, armed robbery, prostitution, kidnapping because the educational system has failed to empower the products with skills for economic security. The government is doing something at federal and state level by introducing entrepreneurship education centres in universities. This policy of making entrepreneurship education compulsory for all university students will help to build the national economy and achieve the educational goal that says "that education shall be to acquired both physical and intellectual skills which will enable individuals to be self-reliant and useful members of the society (FRN, 2004:36). 
With the introduction of entrepreneurship education in universities, before students graduate, they will acquire skills that will enable them to set up or establish small scale businesses on their own for a stable source of financial income. This steady income can allow for the on-going maintenance of the standard of living. Entrepreneurship education is a strong weapon of creating financial assets that can break the generational cycle of poverty and also build economic security over a life time if it is well managed. Management connotes the process of planning, organizing, supervising, directing, coordinating, leading human and materials resources within an organization with the aim of achieving its goals and objectives. For entrepreneurship education to achieve its goal there is need for proper management of resources like qualified personnel, manpower development, curriculum content, provision of instructional methods, physical facilities and others. Seeing the prevailing economic conditions, policy makers all over the world including Nigeria have started recognizing the pivotal role that entrepreneurship skills is bound to plays in the rejuvenation and growth of their national economies. Graduates dependence on their parents and others is increasing but entrepreneurship education if properly managed is capable of forestalling this problem.

However, despite all these laudable efforts by the government and university management, entrepreneurship education has not produced desired result even though it is still in the infant stages in some universities in Nigeria. The level of unemployment and poverty is still very high causing economic insecurity in the country. Proper management of entrepreneurship education will lead to strong and sustainable economy in the nation. So many university graduates are still struggling for white collar jobs that is not available for the great number of graduates. Research statistics according to the National Bureau of Statistic (NBS) in Nigeria has shown that unemployment incidence in Nigeria affects energetic youths within the ages of 15-24 (41.6\%) and 25-44 (17\%) years more than any other age groups in Nigeria (NBS, 2011). Economy grows and cause national development when the individuals have stable income to support a standard of living. How is this type of education being managed? It is against this background that the researchers want to find out whether there is a significant relationship between the management of entrepreneurship education and economic security?

\section{Concept of Entrepreneurship Education}

The concept of entrepreneurship has a wide range of meaning and it will be better to look at it from the root of who is an entrepreneur? the term entrepreneur is a French word "entreprende" which means to "undertake". An entrepreneur is that person who conceives of an idea, utilizes identify opportunities by employing the factors of production; land, labour, capital and time towards productive ends by way of bringing about appropriate innovation either in the production process by revitalizing an existing or beginning an entirely new business. The innovation results in the product of goods and services which will help in solving socio-economic problems in the society (Igwe, 2009). Pinson (2010) opines entrepreneur as an individual who starts a business to follow a vision, to make money, to be master of his or her own and a risk taker. McClelland (1961) argues that the entrepreneur is the central figure in economic growth that where a society is endowed with large amounts of natural resources, blessed with favourable trade opportunities and internal political stability, growth may still not take place unless individuals take advantage of the opportunities of businesses available. In explaining some of the qualities of entrepreneurs, McClelland (1961) in Nwachukwu (2009), states that they must be reasonable risk takers, self confident, hard workers, goal setters, accountable, innovative and in addition must possess leadership qualities, be original, creative, flexible and resourceful.

Entrepreneurship education is a problem solving approach to students' empowerment that is capable of leading them to gain the skills required to plan, start, run and grow a business that focuses on innovation and development of new products and services (Inegbenebor, 2006). Entrepreneurship education is a means of inculcating entrepreneurial skills in students to enable them create, build and manage a business of their own. Bateman and Snell (1999) defined entrepreneurship as a manifestation of effective control of human intelligence, skills and financial resources to achieve great profit. Gana (2001) presents entrepreneurship as the willingness and ability of an individual to seek out investment opportunities in an environment and be able to establish and run an enterprise successfully based on the identified opportunity. Entrepreneurship education is the process of providing individuals with the ability to recognize business opportunities and the insight, self-esteem, knowledge and skills to act on them (Colin \& Jack, 2004). It is about transforming an idea into reality and becoming self reliance and job creator. It is promoted by the spirit of capitalism which in turn promotes economic growth and development through job creation, increasing output of goods and services, enhancing technological innovation, enhancing the per capital level of income, the standard of living and increasing the level of government revenue through taxation (Etuk \& Mbat, 2010). Without entrepreneurs economics all over the world would remain stagnant and demand for goods and services would always exceed the supply. 
This unemployment of university graduates and poverty that is increasing will not allow a strong and sustainable economy in the country. Ford (2013) in his research discovered that would wide, poor households have a hard time building assets. Their incomes are barely adequate to cover daily living expenses, leaving them few, if any, resources to save for emergencies or toward long-term economic security. Most governments lack adequate social protection programmes to reduce the vulnerability of their citizens. Uchendu, Akuegwu and Odigwe (2013) in their work on investing in human resources development for entrepreneurship education in universities in Cross Ricer State revealed that investment in human resource development for entrepreneurship education is significantly low. A good stock of entrepreneurship education instructors with relevant qualifications, competent and transferable skills constitute a great asset to the development of students for economic security (Daniel, 2012).

\section{The Problem}

University education is expected to equip its recipients with skills and competences that will make them to be self-reliant and useful members of the society by contributing to economic and developmental strides in the nation. Unfortunately, this aim seems not to be realized considering the high rate of graduates dependability and un-employability. Entrepreneurship education has being made more of the theoretical teaching where it is adopted at all instead of being a practical course in which students are exposed to skills acquisitions to be able to face the challenges of entrepreneurship. Even at that, facilities that would have enhanced the acquisition of practical knowledge of entrepreneurship education are lacking. Personnel, teaching it are in short supply making the few available ones to be over loaded which calls to question their productivity level. All these, results to students not having adequate entrepreneurship skills that will enable them to be self dependent and being economically secured. Thus, students upon their graduation become vulnerable to continuous dependent on their parents and significant others for their wellbeing. This also accounts for a major reason for high unemployment rate among graduates. However, measures have been taken to make entrepreneurship education result oriented with a view to provide a tool for economic security. For instance, the course is now compulsory for all students in the universities that have entrepreneurship centres. Inspite of all these, economic dependence among students and graduates is still on the rise. It is against this position that the problem of this study is stated as: What relationship would Entrepreneurship Education has with economic security?

\section{Hypotheses}

H01:Management of entrepreneurship education in terms of qualified personnel, curriculum content, adequate funding, instructional methods and physical facilities has no significant relationship with economic security in universities Cross River State, Nigeria.

H02: Management of entrepreneurship education in terms of qualified personnel, curriculum content, adequate funding, instructional methods and physical facilities for economic security is not significantly influenced by university type in Universities in Cross River State, Nigeria.

\section{Methodology}

This study locale was in Cross River State in the south-south geopolitical region of Nigeria. It is one of the oil producing states with political and economic capital in Calabar. The study focused on two universities in the state-one conventional and the other specialized. Ex-post facto design was adopted for the study. The total population was made up of forty (40) core and general managers of entrepreneurship development centres in both universities. The total enumeration or census sampling technique was adopted to select all managers of entrepreneurship projects in the two universities which came to 40. Instrument for data collection was titled 'Managing Entrepreneurship Education for Economic Security Questionnaire' (MEEESQ). It had two sections A and B. Section A consisted of 5 demographic variables, section B contained 30 items, 6 of which measured each of the five variables used in the study. The instrument was validated by experts in measurement and evaluation, while the trial test using Crunbach alpha reliability method gave rise to coefficient ranging from ' $r$ '- 0.70 - ' $r$ '- 0.82 . These figures were considered reliable for use in conducting this study. Data collection was carried out by the researcher personally, this measure gave a 100\% return rate. The data collected were analyzed statistically using Pearson's Product Moment Correlation and Independent t-test. 


\section{Results}

\subsection{Hypothesis 1: Management of entrepreneurship education has no significant relationship with economic security.}

Table 1: Pearson's product Moment Correlation Analysis of Management of Entrepreneurship Education and Economic Security, $N=40$

\begin{tabular}{|c|c|c|c|}
\hline \multicolumn{4}{|c|}{ Entrepreneurship Education and Economic Security, $N=40$} \\
\hline Variables & $\mathbf{x}$ & SD & rxy \\
\hline Qualified personnel x1 & 9.92 & 3.08 & 0.53 \\
\hline Curriculum Content $\mathrm{x} 2$ & 10.02 & 3.41 & 0.33 \\
\hline Adequate funding $\mathrm{x} 3$ & 11.04 & 2.92 & 0.41 \\
\hline Instructional methods $x 4$ & 10.86 & 2.83 & 0.38 \\
\hline Physical facilities $\times 5$ & 10.91 & 3.10 & 0.49 \\
\hline Economic security $\mathrm{y}$ & 15.71 & 3.64 & \\
\hline
\end{tabular}

Significant at $0.05, \mathrm{df}=38$, critical r-value $=0.304$

Result presented in Table 1 indicated that the calculated r-value were higher than the critical r-value of 0.304 at 0.05 level of significance and 38 degree of freedom in respect of qualified personnel $(r-0.53)$, curriculum content $(r=0.33)$ adequate funding $(r=0.41)$, instructional methods $(r=0.38)$ physical facilities $(r=49)$. With these results, the null hypothesis was rejected. It therefore means that management of entrepreneurship education in universities has a significant relationship with economic security.

6.2 Hypothesis 2: Management of entrepreneurship education for economic security is not influenced by university type.

Table 2: Independent t-test analysis of the influence of university type of managing entrepreneurship education

\begin{tabular}{lccccc} 
& \multicolumn{3}{c}{ Conventional (N-20) } & \multicolumn{3}{c}{ Specialized (N-20) } \\
\hline Variables & $\mathbf{X}$ & $\mathbf{S D}$ & $\mathbf{X}$ & SD & t-value \\
\hline Qualified personnel & 18.86 & 1.95 & 19.16 & 1.70 & -0.706 \\
Curriculum content & 17.80 & 2.24 & 18.05 & 1.93 & -0.465 \\
Adequate funding & 19.64 & 1.80 & 20.21 & 1.64 & -0.818 \\
Instructional methods & 17.23 & 1.96 & 18.40 & 1.82 & -0.524 \\
Physical facilities & 18.72 & 1.59 & 19.65 & 1.24 & -0.432
\end{tabular}

Not significant at $0.05, \mathrm{df}=38$, critical t-value $=2.021$

Results presented in Table 2 indicated that the calculated t-values were lower than the critical t-value of 2.021 at 0.05 level of significance and 38 degree of freedom in respect of qualified personnel $(t=-0.706)$, curriculum content $(t=-0.465)$, adequate funding ( $\mathrm{t}=--0.818$ ), instructional methods ( $\mathrm{t}=-0.524)$, physical facilities ( $\mathrm{t}=-0.432)$. With this result, the null hypothesis was not rejected. This means that conventional university managers do not differ from the specialized university counterparts in management of entrepreneurship education.

\section{Discussion of Results}

The result of hypothesis one revealed that management of entrepreneurship education has a significant relationship with economic security. This necessitated the rejection of the null hypothesis and accepting the alternate hypothesis. The finding suggests that management of entrepreneurship education has a significant relationship with economic security in 
terms of qualified personnel, curriculum content, adequate funding, instructional methods and physical facilities. This result by implication means that the management of entrepreneurship education in terms of qualified personnel, curriculum content, funding, instructional method, physical facilities influences economic security, so all must be properly managed for better result for economic security. This finding is supported by Daniel's (2012) work that a good stock of entrepreneurship education instructors with relevant qualifications, competent and transferable skills constitute a great asset to the development of students for economic security. For entrepreneurship education to have meaningful influence on students' economic security, there must be the right and qualified personnel in place both academic and nonacademic.

Hosseini and Ahmadi (2011) reported that entrepreneurial education has a tremendous potential to help in the employment status of university students. Entrepreneurship education though still in the infant stage or has not witnessed a long period of existence in Nigeria, being a recent entrant into the university curriculum, its impact is likely to produce significant results in tackling unemployment and poverty problems if properly managed at university level. Proper management of human and material resources in respect of planning, organizing, supervising, directing, controlling, coordinating and budgeting will enhance students' self reliance and job creation given rise to economic security.

Results of hypothesis two indicated that management of entrepreneurship education for economic security is not influenced by university type. This means that conventional and specialized universities in Cross River State do not differ significantly in their management of human and material resources in entrepreneurship education. This finding suggests that management of entrepreneurship education for economic security in conventional university in terms of qualified personnel, curriculum content, adequate funding, instructional methods, and physical facilities is the same in the specialized university. Ordinarily, one would have expected the conventional (federal) university to fare better than the specialized (state-owned) universities. Bassey, Akuegwu, Umoren, Ekpiken, Udida, Egbona and Uche (2008) which disclosed that state owned university made more provision for entrepreneurship education than their federal counterparts.

\section{Conclusion}

On the strength of the findings, it was concluded that management of entrepreneurship education in respect of qualified personnel, curriculum content, adequate funding, instructional method and physical facilities has a significant relationship with economic security. Also, university type does not influence the management of entrepreneurship education for economic security. There is need for proper management of human and material resources for strong and sustainable which leads to economic security in the nation.

\section{Recommendations}

i. Priority should be accorded to the management of entrepreneurship education for economic security in our universities

ii. Entrepreneurship education as a compulsory course requires practical demonstration so that it will achieve its desired purpose. Proper management of human and material resources will help the students to acquire skills and competencies for self-reliance and useful members of the society contributing to economic sustainability and national development.

\section{References}

Bateman, T.S. \& Snell, S. A. (1999). Management: Building Competitive Advantage. Fourth Edition Boston: Iron McGraw-Hill.

Childstats.gov. American's Children: Key National Indicators of well Being (2007). Economic Circumstances. Wikipedia.org/wiki/ economic security. (Accessed from the internet on 2/10/2013)

Daniel, O. I. (2012). Management of University-wide Entrepreneurship Education and Students' Venture Creation Propensity in SouthSouth, Nigeria. Unpublished Ph.D. Thesis. University of Calabar.

Etuk, E. J. \& Mbat, D. O. (2010). Entrepreneurship Development for Students and Practitioners. Abuja: Century Frontiers Investment Ltd.

Ford (2013). Building Economic Security over a lifetime. htt://www.economicsecurity.com (Accessed from the internet on 2/10/2013).

Gana, J. S. (2001). Entrepreneurship in Nigeria. Enugu: Jofegan Associate Ltd.

Hossini, S. J. F. \& Ahmadi, H. (2011) Affective Factors Contributing to Entrepreneurial Attitudes of University Students in Iran. Annuals of Biological Research, 2(2), 366-371.

Igbatighi, F. A. (2007). Level of Awareness in Entrepreneurial Development among the students of Tertiary Institutions in Nigeria. 
International Journal of Research in Education. 4(1\&2), 296-304

Igwe, L E. B. (2009). Managing Entrepreneurship Education in a period of global Depression. African Journal of Educational Research and Development (AJERD). 3(2), 20-30.

Inegbenebor, A.U. (Ed.) (2006). The Fundamentals of Entrepreneurship. Lagos: Malthouse Press Limited.

McClelland (1961) in Nwachukwu (2009). The Practice of Entrepreneurship in Nigeria. Port Harcourt: Africana - FEP Publishers Ltd.

McClelland, D. C. (1961). The Achieving Society. New York: Van Nostrand.

Pinson, H. (2010). In thinking (2010). Entrepreneurship. What is its definition? www.thinkinglike.com/essay/intrepreneurdefinition.html. retrieved 2nd Oct. 2013

Rupert, M. (2007). International Relations Theory. Oxford: Oxford University Press.

Uchendu, C. C., Akuegwu, B. A. \& Odigwe, F. N. (2013). Investing in Human Resource Development for Entrepreneurship Education in Universities in Cross River State. 